\title{
MENARDIIFORM PLANKTONIC FORAMINIFERA STRATIGRAPHY FROM MIDDLE PLEISTOCENE TO HOLOCENE IN THE WESTERN SOUTH ATLANTIC
}

\author{
KAREN BADARACO COSTA, EDMUNDO CAMILLO JR, \\ ANA CLÁUDIA AOKI SANTAROSA, FABIANE SAYURI IWAI \\ Laboratório de Paleoceanografia do Atlântico Sul, Instituto Oceanográfico, Universidade de São Paulo (LaPAS/IO-USP). \\ Praça do Oceanográfico, 191, 05580-120, Cidade Universitária, São Paulo, SP, Brazil. \\ karen.costa@usp.br,edmundo@usp.br,anasantarosa@gmail.com,sayuri.iwai@gmail.com
}

\section{JULIANA PEREIRA DE QUADROS}

Centro de Formação em Ciências Ambientais, Instituto de Humanidades, Artes e Ciências, Universidade Federal do Sul da Bahia (CFCAm/IHAC-UFSB). Rodovia BR-367 km 10, s/n, 45810-000, Porto Seguro, BA, Brazil.jquadros@ufsb.edu.br

\section{ITAMAR IVO LEIPNITZ}

Instituto Tecnológico de Micropaleontologia da Universidade do Vale do Rio dos Sinos (ITT-FOSSIL/UNISINOS), Av. Unisinos, 950, 93022-000, São Leopoldo, RS, Brazil.

\section{FELIPE ANTONIO DE LIMA TOLEDO}

Laboratório de Paleoceanografia do Atlântico Sul, Instituto Oceanográfico, Universidade de São Paulo (LaPAS/IO-USP), Praça do Oceanográfico, 191, 05580-120, Cidade Universitária, São Paulo, SP, Brazil.ftoledo@usp.br

\begin{abstract}
We studied the Middle Pleistocene to Holocene menardiiform planktonic foraminifera (MPF) stratigraphy in six continuous deep-sea sediment cores recovered from the Brazilian continental slope to evaluate its use in climatic characterization and as a reliable biostratigraphic tool in the western South Atlantic. For this purpose, an important issue was to construct a robust local biochronological framework for the past $772 \mathrm{ky}$ in the western South Atlantic (Santos Basin). The oxygen isotope chronostratigraphic control allowed us to recalibrate the MPF events in the Santos Basin and identify diachronous bioevents. The bio-horizons found in the Santos Basin, such as the $\mathrm{V} / \mathrm{W}$ and T/U (bio)zone boundaries, were found in a different chronostratigraphic position compared to previous studies. Results indicate that typical cyclic disappearances and reappearances of the MPF are not synchronous throughout the Atlantic Ocean and should not be employed for 'climatic zonation'. This asynchronous evidence also provides information on the timing of the mechanisms responsible for the proliferation of these species throughout the Atlantic Ocean. Therefore, we strongly recommend that a local biochronological framework should be used for inter-basin comparisons and also accumulation rate estimates, both for paleoclimatic studies and continental slope geohazard assessment.
\end{abstract}

Keywords: planktonic foraminifera, biochronology, Santos Basin, Brazilian margin, climatic zonation.

RESUMO - Este trabalho apresenta a estratigrafia dos foraminíferos planctônicos menardiformes (FPM), do Pleistoceno Médio ao Holoceno, em seis registros marinhos contínuos da margem continental do sudeste brasileiro. Através deste estudo foi possível avaliar a sua utilização em caracterizações paleoclimáticas e sua efetividade como indicador bioestratigráfico no Atlântico Sudoeste. Para isto foi importante estabelecer localmente um arcabouço biocronológico robusto dos últimos 772 ky na porção oeste do Atlântico Sul (Bacia de Santos). O controle cronoestratigráfico por isótopos de oxigênio permitiu a calibração dos eventos FPM na Bacia de Santos e a identificação de diacronismo com outras localidades. Alguns bio-horizontes na Bacia de Santos, como os limites das biozonas V/W e T/U, foram identificados em posição cronoestratigráfica distinta daquelas reconhecidas em estudos prévios. Os resultados indicam que o ciclo típico de desaparecimentos e reaparecimentos do FPM não é sincrônico ao longo do Oceano Atlântico e, por isso, deve-se ter cautela ao utilizá-lo como "zoneamento climático". Essa evidência assíncrona fornece também informações sobre o tempo dos mecanismos responsáveis pela proliferação dessas espécies no Oceano Atlântico. Portanto, recomenda-se que um arcabouço biocronológico local seja utilizado para comparações entre bacias e também para estimativas de taxas de acumulação, tanto para estudos paleoclimáticos como para avaliação de riscos geológicos no talude.

Palavras-chave: foraminíferos planctônicos, biocronologia, Bacia de Santos, margem continental brasileira, zonação climática. 


\section{INTRODUCTION}

First and last appearances of Quaternary planktonic foraminifera representing primarily non-evolutionary migrational events are only of regional significance (Thunell, 1984). Therefore, their application for chronostratigraphic purposes may be questioned. The western South Atlantic, specifically the Brazilian continental margin, lacks high resolution and continuous records that allow the development of a biostratigraphic framework with a reasonable resolution and chronological control. A robust stratigraphic framework is important to infer changes in patterns of sedimentation and the continuity of records in order to support paleoceanographic studies and also industry surveys. For paleoceanographic studies, the chronostratigraphic information is essential for a good age model. The increasing interest in exploring deep-water and ultra-deep water deposits on the Brazilian continental slope demands chronological-controlled biostratigraphic and sedimentological studies. Geohazards and slope stability assessments use them as a basis for establishing permanent equipment for production and transportation of petroleum (Vicalvi, 1997).

The increase in Jumbo piston coring along the Brazilian continental margin and high-resolution sampling offer an opportunity for a reassessment and refinement of the planktonic foraminiferal biostratigraphy, by integrating isotopic data, side-scan sonar images, and multichannel seismic profiles to a well-established biostratigraphic zonal scheme (Kowsmann et al., 2015; Toledo et al., 2016). Moreover, high-resolution records provided with chronological control improve the knowledge on the temporal range of microfossil species. Chronological control may be provided by isotopic stratigraphy. Therefore, biostratigraphic investigations associated with isotopic chronological control allow the conventional planktonic foraminifera zonation to be chronologically revised in Brazilian margin.

In 1968, Ericson \& Wollin described ten biozones based on the presence/absence of Globorotalia menardii complex for the entire Quaternary. The biozones were designated from Q (1.75-2 Ma) through Z (representing the Holocene). This zonation was first observed by the authors at the equatorial Atlantic and later in other parts of the Atlantic, allowing the correlation among Atlantic records. Thenceforward, the frequency variations of climate-controlled menardiiform planktonic foraminifera (MPF) have become a standard biostratigraphic practice to divide the Quaternary into zones and subzones in the Atlantic Ocean. This scheme is widely used by academics and industries (Kohl, 2004; Martinez et al., 2007; Vicalvi, 2013; Broecker \& Pena, 2014; Kowsmann et al., 2015).

Most of previous studies in the western South Atlantic had recognized only biozones W to Z (Damuth, 1975; Bé et al., 1976; Vicalvi \& Palma, 1980; Rodrigues \& Carvalho, 1980; Vicalvi, 1997, 1999, 2013; Toledo, 2000; Portilho-Ramos et al., 2006; Sanjinés, 2006; Cremer et al., 2007; Oliveira et al., 2007; Araújo \& Machado, 2008; Camillo et al., 2015; Kowsmann et al., 2015). There are few studies reaching the Biozone T in the western South Atlantic (Pätzold et al., 1993, 1999; Ferreira et al., 2012; Vicalvi, 2013; Toledo et al., 2016). However, most of these studies are not chronologically calibrated; they adopt zones/subzone boundary ages established by previous studies from different geographical locations and environments (Damuth, 1975; Martin et al., 1993; Martin \& Fletcher, 1995; Kohl et al., 2004).

Several studies on the Brazilian continental margin described climatic fluctuations (glacial/interglacial) based on the previously established thermal-control of MPF occurrence (Vicalvi, 1997, 1999, 2013; Portilho-Ramos et al., 2006; Ferreira et al., 2012), where glacial/interglacial episodes are related to their absence/presence. Nevertheless, as pointed out by Martin et al. (1993, p. 156) "the relative abundance of the Globorotalia menardii complex in Zones $\mathrm{Z}$ and $\mathrm{Y}$ agrees with oxygen isotopes stages $1-5$. However, below Zone Y the relationship between Ericson \& Wollin (1968) zonation and the oxygen isotope curve is often ambiguous, which has no doubt encouraged most workers to utilize the oxygen isotope curve in their studies instead". However, it is possible to carry out a calibration of these bioevents and/or biozones to a robust age model based on the oxygen isotope record and thus make the practice of using the MPF stratigraphy as a reliable chronological tool on a regional scale. Nonetheless, the reason for the successive appearances and disappearances of this species observed in the Atlantic Ocean has not yet been understood (Sexton \& Norris, 2011; Broecker \& Pena, 2014).

Here, we recognize the Middle Pleistocene to Holocene MPF stratigraphy in six continuous deep-sea sediment cores recovered from the Brazilian continental slope in Santos Basin and recalibrate the bioevents based on a robust local biochronological framework for the past $772 \mathrm{ky}$ to elucidate its use in climatic characterization and as reliable biostratigraphic tool in the western South Atlantic. Furthermore, these new data can contribute to elucidate the mechanism that determines the MPF cyclic occurrence in the Atlantic Ocean.

\section{REGIONAL SETTING}

The study area (Figure 1) is in the Santos Basin and comprises the Lula field (formerly Tupi field) ring-fence, one of the largest oil reserve discoveries in offshore Brazil in the past decade (Mohriak et al., 2012). The continental slope here is affected by salt tectonics and is characterized by the presence of minibasins surrounded by salt ridges with crestal grabens. In the area of the ring-fence, the flowage of salt created a foldbelt that produced extensive uplift and erosion, followed by the deposition of a contourite drift. This erosion and subsequent burial resulted in a trend of subdued seafloor relief (Mohriak et al., 2012; R. Kowsmann, pers. comm.). A seismic study in the region suggests that sedimentation from Neogene to Recent time was dominated by surface oceanic circulation redistribution of sediments transferred to the basin during both relative sea-level highstands and lowstands (Duarte \& Viana, 2007). 
A)

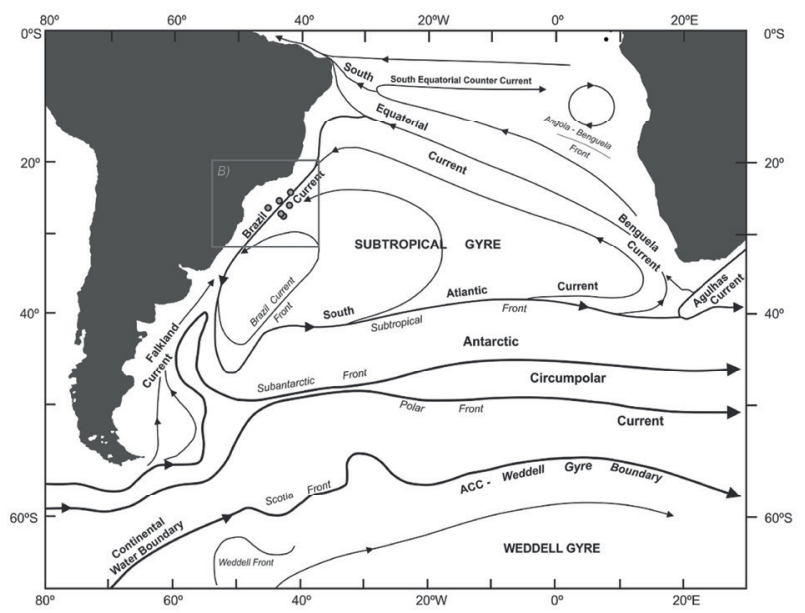

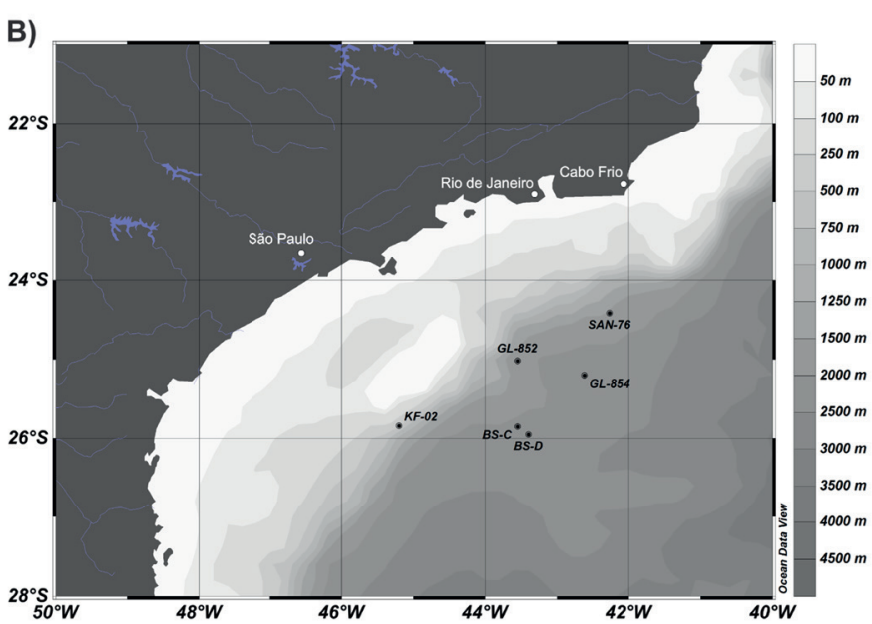

Figure 1. A, Location map, modern surface circulation (modified from Peterson \& Stramma, 1991); B, physiography of the study area.

The presence of the warm, salty and oligotrophic Tropical Water (TW) in the upper $200 \mathrm{~m}$, dominates the modern surface oceanography along the Brazilian coast (Figure 1). The TW is transported southwards by the Brazil Current (BC), the western branch of the South Atlantic subtropical gyre. The upwelling of deeper nutrient-rich, cooler and fresher South Atlantic Central Water (SACW) eventually fertilizes the upper layer. Near $22^{\circ} \mathrm{S}$ (Cabo Frio), the orientation of the South American coastline changes abruptly from a predominantly north-south to predominantly east-west orientation. The flow divergence caused by this change in the coastline orientation, associated with the northeasterly wind lead to the formation of strong BC meandering (Campos et al., 1995). In turn, these meanders result in a relatively strong upwelling regime, which pumps large amounts of the SACW to the upper slope and continental shelf (Campos et al., 2000).

As shown by Stramma \& England (1999), Boebel et al. (1999), Wienders et al., (2000) and Rodrigues et al. (2007), there is evidence of the southern branch of the South Equatorial Current (sSEC) bifurcation tilting to the south with depth. Near the surface $(0-100 \mathrm{~m})$, the sSEC bifurcates at around $14^{\circ} \mathrm{S}$ in the TW; at $200 \mathrm{~m}$ it bifurcates at $18.6^{\circ} \mathrm{S}$ in the SACW; at $400 \mathrm{~m}$ it bifurcates at about $21^{\circ} \mathrm{S}$ in the SACW; at 600 and 800 a weaker sSEC bifurcates at 23.6 and $25.5^{\circ} \mathrm{S}$, respectively, in the Antarctic Intermediate Water (AAIW). The latter bifurcation is also called the Santos Bifurcation. Since SEC is part of the wind-driven subtropical gyre, its bifurcation is dependent on the wind regime over the basin. Seasonal changes in the wind field and the migration of the Intertropical Convergence Zone (ITCZ) and Subtropical Convergence Zone (SACZ) are responsible for changes in the upper-level circulation.

During austral winter/summer, when the ITCZ is at its northernmost/southernmost position and the SE/NE trade winds extend well into the northern hemisphere, the flow of the North Brazil Current (NBC) is strengthened/weakened, reaching a maximum/minimum during austral spring/fall which is counterbalanced by a weakened/strengthened
BC (Johns et al., 1998; Kim \& Schneider, 2003). The strengthening of the $\mathrm{BC}$ results in a southward displacement of the Brazil-Malvinas Confluence (Matano et al., 1993; Goni \& Wainer, 2001; Chiessi et al., 2007).

\section{MATERIAL AND METHODS}

\section{Cores}

Six piston cores recovered from the slope of Santos Basin were studied, spanning a depth range of 827 to $2220 \mathrm{~m}$ (Table 1). The cores GL-852, GL-854, SAN-76, and KF-02 can be found at the South Atlantic Paleoceanography Lab repository, situated at the Oceanographic Institute of the University of São Paulo (LaPAS - IOUSP); cores BS-C, BS-D can be found at the Technological Institute of Micropaleontology repository, located at the Vale dos Sinos University (ITT Fossil - UNISINOS). The cores location, depth of the sampling site, recovered length; number of samples and stratigraphic resolution are shown in Table 1.

According to the lithology, the cores are composed of marl $\left(\mathrm{CaCO}_{3}\right.$ content between $\left.60-30 \%\right)$, carbonate-rich mud (30-18\%) and carbonate-poor mud (18-5\%). Conepenetrometer data from Petrobras in the same location as the long cores GL-852, GL-854, BS-C, and BS-D assured that the sedimentary record is continuous, with no observed hiatus.

\section{Foraminifera preparation}

The sediment was washed through a $63 \mu \mathrm{m}$ mesh sieve. The residue was dried at $50^{\circ} \mathrm{C}$ and the $>150 \mu \mathrm{m}$ fraction (cores GL-854, SAN-76, KF-02, and GL-852) splitted with a microsplitter until a 300 planktonic foraminifera aliquot was obtained. The sample preparation and planktonic foraminifera biostratigraphy for cores BS-C and BS-D were previously published by Ferreira et al. (2012).

To make the study chronostratigraphically useful, the planktonic foraminifera counting was especially addressed to the recognition and vertical distribution of species that are used in the standard Quaternary biostratigraphic zonation 
scheme of Ericson \& Wollin (1968). The MPF observed in this study were: Globorotalia menardii, G. tumida, G. flexuosa and G. ungulata (Hayward et al., 2018). The intervals of absence, or virtual absence, of MPF, are characterized by a conspicuous decrease of their relative abundance. MPF were considered to be absent, or virtually absent, during intervals where their abundance values were less than or equal to $1 \%$, or when they eventually exceeded this value, the relative abundance curve did not show a clear increasing trend.

\section{AMS dating}

Accelerator Mass Spectrometer radiocarbon dating was conducted on the planktonic foraminifer Globigerinoides ruber (white morphotype) (>150 $\mu \mathrm{m}$ size) from three samples of core GL-854, four samples of core SAN-76, and eleven samples of core KF-02 (Table 2), at the National Ocean Science Accelerator Mass Spectrometer Facility (NOSAMS), Woods Hole Oceanographic Institution (WHOI). The selected shells exhibited a good preservation state and no overgrowth or dissolution effects were observed. The radiocarbon ages were transformed into calibrated ages by first subtracting the reservoir age (Table 2) according to Butzin et al., (2005) and then applying the Fairbanks et al. (2005) calibration curve (version Fairbanks0107) using the software available at http://radiocarbon.LDEO.columbia.edu/.

\section{Stable isotopes}

The stable isotopic analyses of cores GL-854 (409 samples) and GL-852 (302 samples) were conducted at the Scientific and Technological Centers of the University

Table 1. Cores and sampling information.

\begin{tabular}{|c|c|c|c|c|c|}
\hline Core ID & Core Location & Depth (mbsl)* & $\begin{array}{l}\text { Recovered } \\
\text { Length (m) }\end{array}$ & $\begin{array}{c}\text { Samples } \\
\text { Analyzed }(\mathrm{N})\end{array}$ & $\begin{array}{c}\text { Stratigraphic } \\
\text { Resolution }(\mathrm{cm})\end{array}$ \\
\hline GL-854 & $25^{\circ} 12^{\prime} \mathrm{S} / 42^{\circ} 37^{\circ} \mathrm{W}$ & 2220 & 20.37 & 409 & 5 \\
\hline GL-852 & $25^{\circ} 01^{\prime} \mathrm{S} / 43^{\circ} 33^{\circ} \mathrm{W}$ & 1938 & 20.33 & 302 & 10 \\
\hline BS-C & $25^{\circ} 51^{\prime} \mathrm{S} / 43^{\circ} 33^{\prime} \mathrm{W}$ & 2148 & 20.43 & 108 & 30 \\
\hline BS-D & $25^{\circ} 57^{\prime} \mathrm{S} / 43^{\circ} 24^{\prime} \mathrm{W}$ & 2171 & 21.21 & 80 & 30 \\
\hline SAN-76 & $24^{\circ} 25^{\prime} \mathrm{S} / 42^{\circ} 16^{\prime} \mathrm{W}$ & 1682 & 4.19 & 36 & 5 \\
\hline KF-02 & $25^{\circ} 50^{\prime} \mathrm{S} / 45^{\circ} 12^{\prime} \mathrm{W}$ & 827 & 4.89 & 218 & 2 \\
\hline
\end{tabular}

*mbsl: meters below sea level

Table 2. Radiocarbon datings and respective calibrated ages.

\begin{tabular}{|c|c|c|c|c|c|c|}
\hline Core ID & $\begin{array}{l}\text { Sample depth } \\
(\mathrm{cm})\end{array}$ & $\begin{array}{l}{ }^{14} \mathrm{C} \text { age } \\
\text { (years) }\end{array}$ & $\begin{array}{l}\text { Error } \\
\text { (years) }\end{array}$ & $\begin{array}{c}\text { Reservoir Effect } \\
\text { (years) }\end{array}$ & Calibrated age (years) & $\begin{array}{c}\text { Error }(1 \sigma) \\
\text { (years) }\end{array}$ \\
\hline \multirow[t]{11}{*}{ KF-02 } & 2 & 615 & 30 & 271 & 404 & 57 \\
\hline & 45 & 850 & 15 & 271 & 579 & 34 \\
\hline & 99 & 1080 & 50 & 271 & 720 & 41 \\
\hline & 149 & 2910 & 20 & 271 & 2750 & 9 \\
\hline & 234 & 5230 & 25 & 271 & 5673 & 30 \\
\hline & 318 & 7750 & 30 & 271 & 8319 & 39 \\
\hline & 360 & 9660 & 60 & 271 & 10611 & 78 \\
\hline & 420 & 10550 & 60 & 271 & 12048 & 102 \\
\hline & 436 & 11150 & 40 & 271 & 12776 & 45 \\
\hline & 464 & 12400 & 55 & 271 & 13916 & 69 \\
\hline & 488 & 12750 & 65 & 271 & 14437 & 157 \\
\hline \multirow[t]{4}{*}{ SAN-76 } & 13 & 3010 & 50 & 263 & 2834 & 53 \\
\hline & 148 & 13450 & 35 & 263 & 15357 & 110 \\
\hline & 320 & 19300 & 33 & 263 & 22609 & 79 \\
\hline & 416 & 29400 & 36 & 263 & 34554 & 146 \\
\hline \multirow[t]{3}{*}{ GL-854 } & 0 & 3982 & 35 & 268 & 4442 & 40 \\
\hline & 14 & 20032 & 130 & 268 & 23931 & 164 \\
\hline & 51 & 37832 & 250 & 268 & 42850 & 275 \\
\hline GL-852 & - & - & - & - & - & - \\
\hline BS-C & - & - & - & - & - & - \\
\hline BS-D & - & - & - & - & - & - \\
\hline
\end{tabular}


of Barcelona (CCiT-UB), on a Finnigan MAT252 mass spectrometer with an integrated automated carbonate device. Samples from cores SAN-76 (36 samples) and KF-02 (218 samples) were analyzed at the Woods Hole Oceanographic Institution (WHOI) Micropaleontology Mass Spec Facility using a Finnigan MAT252 with a Kiel III Carbonate Device. The isotopic analysis of cores BS-C (63 samples) and BS-D (47 samples) were performed at the Stable Isotope Laboratory of the University of California, USA. Corrected delta values are expressed relative to international standards of VPDB (Vienna - Pee Dee Belemnite) for $\delta^{18} \mathrm{O}$. Analyses were performed on the planktonic foraminifera species Globigerinoides ruber white morphotype $(>150 \mu \mathrm{m})$ and the benthic species Cibicidoides wuellerstorfi $(>150 \mu \mathrm{m})$.

\section{Chronology}

The age models of the six cores are shown in Figure 2. The age models were built based on the correlation of the benthic $\delta^{18} \mathrm{O}$ from the Santos Basin with the benthic oxygen isotope stack of Lisiecki \& Raymo (2005), using the software Analyseries 2.0 (Paillard et al., 1996) (Table 3). Marine benthic oxygen isotopes record, primarily, the variation of global ice volume, which in turn truthfully determines glacial and interglacial intervals. AMS ages and glacial terminations (VIII - I) were used as control points. GL-854 time scale encompasses the last $772 \mathrm{ky}$ and GL-852 the last $322 \mathrm{ky}$ (Toledo et al., 2016). The core GL-854 provides the reference age model. The age models for BS-C and BS-D (Ferreira et al., 2012) were also reassessed by tuning their $\delta^{18} \mathrm{O}$ record to the LR04 stack. Cores KF-02 and SAN-76 have higher resolution during the Holocene, and therefore allow better calibration for this period, especially for the Y/Z boundary. Core SAN-76 chronological framework has been previously published in Toledo et al. (2007), while KF-02 chronology is described in Pivel et al. (2013). As SAN-76 age model was built based on the SPECMAP reference curve (Toledo et al., 2007), we re-examined this record in order to match it to the time scale used here, developing a new age model based on the LR04 reference curve. The age of each sample was calculated by linear interpolation between two consecutive control points in each core. Santos Basin MPF biozones boundaries ages were obtained by calculating the average age of biozone boundaries in all cores from this investigation.

\section{Age Models}

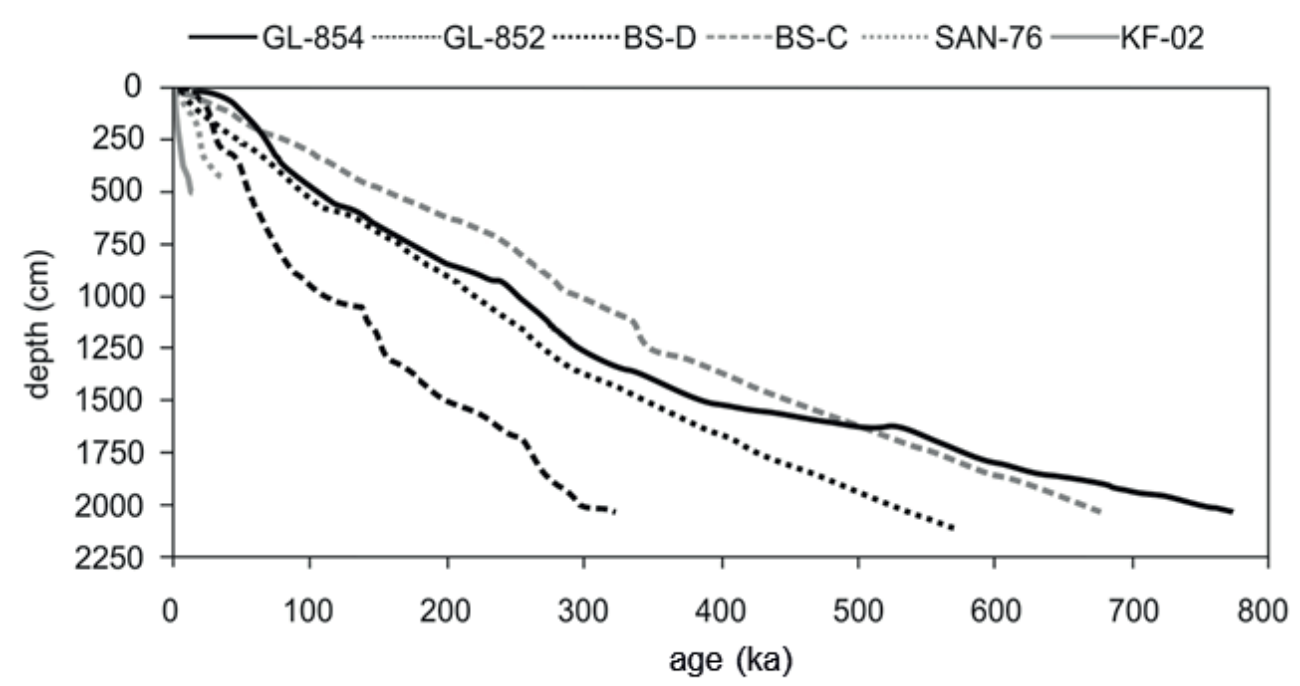

Figure 2. Calibrated age vs. depth plot for cores KF-02, SAN-76, GL-852, BS-D, BS-C and GL-854.

Table 3. Time span, correlation to LR04 and mean sedimentation rates of the studied cores.

\begin{tabular}{cccc}
\hline Core ID & $\begin{array}{c}\text { Time span (ky) } \\
\text { and MIS* }\end{array}$ & Correlation to LR04 & $\begin{array}{c}\text { Mean sedimentation } \\
\text { rate (cm/ky) }\end{array}$ \\
KF-02 & 14 (MIS 1) & 0.7 & 28 \\
SAN-76 & 35 (MIS 3 - MIS 1) & 0.78 & 13 \\
GL-852 & 322 (MIS 9 - MIS 1) & 0.74 & 7.4 \\
BS-D & 568 (MIS 15 - MIS 1) & 0.75 & 4 \\
BS-C & 670 (MIS 16- MIS 1) & 0.77 & 4 \\
GL-854 & 772 (MIS 19- MIS 1) & 0.8 & 4.3 \\
\hline
\end{tabular}




\section{RESULTS}

\section{$\delta^{18} \mathrm{O}$ Stratigraphy}

The $\delta^{18} \mathrm{O}$ stratigraphy for cores GL-854, GL-852, BSC, BS-D, SAN-76, and KF-02 is shown in Figure 3. A comparison of the oxygen isotope records shows a high degree of similarity, as expected for cores from the same basin. The six oxygen isotope records in deep-sea sediments of the Santos basin provide an important tool for stratigraphic correlation. The oxygen isotope signal consistency allows us to define the last nineteen marine isotope stages (MIS) and several isotopic substages, mainly those of MIS 8, MIS 7 and MIS 5 (better visualized in higher resolution cores such as GL-854 and GL852). We adopted the lettered scheme proposed by Railsback et al. (2015) for the identification of MIS and their substages.

\section{Menardiiform Planktonic Foraminifera (MPF) stratigraphy and biochronology}

We recognized seven of the ten biozones described by Ericson \& Wollin (1968), namely, from the oldest to youngest, Biozone T (Middle Pleistocene) to Biozone Z (Holocene) based on the occurrence of the MPF. The Figure 4 shows the relative abundance of the MPF to the total association of planktonic foraminifera in each sample for the six cores considered in this study. We have correlated the biozones, indicated in Figure 4 by dotted lines, with MIS, highlighted by grey bands.

In the Biozone $\mathrm{Z}$, which is the most recent one, MPF is abundant. This biozone is present in all six cores, although the resolution of GL-854, BS-C, and BS-D does not allow a good visualization of its development along time. The Biozone $\mathrm{Z}$ occurs during MIS 1 in all the studied cores (see in Appendix 1). The Biozone $Y$ is characterized by an abrupt decrease in MPF relative abundance. This is considered the biozone with the lowest MPF abundance, and we identified this interval in all six cores. This biozone is traced from MIS $5 \mathrm{~b}$ to MIS 1 . The previous Biozone $\mathrm{X}$ is characterized by the abundant presence of the MPF. According to our chronology, this biozone had an average duration of $40 \mathrm{ky}$ and it was also recognized in cores GL-854 (44.4 ky), BS-C (42.4 ky), BS-D (35.4 ky) and GL-852 (38.1 ky). The Biozone X belongs to MIS 5, from MIS 5e to MIS 5b (see Appendix 1). In the Biozone $\mathrm{W}$, the MPF is absent or virtually absent in a relatively thin layer. These characteristics are consistent in the four cores in which the Biozone W was recognized (GL-854, BS-C, BS$\mathrm{D}$, and GL-852). The Biozone W correlates with the upper portion of MIS 6, which corresponds to the highest isotopic values of this MIS. In the Biozone V, the MPF is consistently abundant. Three of our cores (GL-854, BS-C, and BS-D) show a complete Biozone V.

In core GL-852, the Biozone $\mathrm{V}$ is recognized, but its record does not reach the $\mathrm{V} / \mathrm{U}$ biozone boundary. The Biozone $\mathrm{V}$ is the largest biozone in all cores, both in time span and sediment thickness. A complete Biozone $\mathrm{V}$ had an average time span of $335 \mathrm{ky}$, including eight isotope stages (MIS 13-MIS 6), corresponding to three full glacial-interglacial ( $\mathrm{G}-\mathrm{IG})$ cycles. In GL-852 only half of this biozone ( $167.5 \mathrm{ky}$ ) was recovered. It is observed a lower MPF relative abundance at MIS 12,
MIS 9e and during MIS $8 \mathrm{c}$ in both cores GL-854, BS-C and BS-D. In the Biozone U, the MPF relative abundance values decrease sharply. In the present study, we have recognized this biozone in three cores (GL-854, BS-C, and BS-D). In GL-854, the Biozone U spanned $135 \mathrm{ky}$, while in core BS-C this zone spanned around $140 \mathrm{ky}$, both ranging from MIS 16a to the middle of MIS 13. In BS-D, the Biozone U record does not exceed $66 \mathrm{ky}$, from MIS 14 to middle MIS 13, pointing that this biozone is incomplete in this core. The abundance of MPF characterizes the Biozone $\mathrm{T}$. We recognized this biozone only in cores GL-854 and BS-C. However, Biozone T was incomplete in both cores, being more extended in GL-854 than in BS-C. In GL-854, $135 \mathrm{ky}$ of the Zone T were recognized, from MIS 19 to MIS 16a, while in BS-C we observed only the end of this biozone, coincident with substage MIS 16a, as well as in GL-854.

\section{DISCUSSION}

Historically, the stratigraphy of the MPF was a conventional method for recognizing the Pleistocene glacials/interglacials in deep-sea sediments from the Atlantic Ocean (Schott, 1935; Ericson \& Wollin, 1968; Briskin \& Berggren, 1975). The advent of oxygen isotope stratigraphy became the most reliable method to identify ice ages, since its variations reflect changes in the global ice volume (Ruddiman \& MacIntyre, 1979, 1981; Streeter \& Shackleton, 1979; Curry \& Lohmann, 1982; Shackleton \& Hall, 1984; Pisias et al., 1984; Ruddiman et al., 1986; and others). MPF oscillation is still a very important tool for a rough Pleistocene stratigraphy in the Atlantic Ocean, although there are studies that show the correlation to glacials/interglacials is not straightforward (Martin et al., 1990, Kohl et al., 2004; Martinez et al., 2007). Observing the MPF record and the oxygen isotope stratigraphy in our data (Figure 4), we also found that the association of MPF zones to thermal and glacial-interglacial cycles cannot be sustained, since both linear regression and correlation analysis showed very low values, indicating that there is no significant relationship between MPF and $\delta^{18} \mathrm{O}$, especially on longer time-span cores (GL-852, GL-854, BS-C, and BS-D). Taking as an example the highest resolution core (GL-854), we observed that most interglacial peaks have low MPF abundance values. For a long time, researchers considered biozones such as $\mathrm{T}$ and $\mathrm{V}$, where MPF is abundantly present, as interglacials. Nevertheless, MPF are also present during several glacial intervals, such as MIS 18 and MIS 16 (Biozone T), and MIS 12, MIS 10, MIS 8 and MIS 6 (Biozone V). Likewise, the Biozone U, where MPF is rare or absent (and previously considered as a glacial), comprises only one glacial stage (MIS 14) and two interglacial stages (MIS 15 and MIS 13) (Figure 4). Although the relationship between MPF presence/absence and interglacials/glacials is not straight as it was thought, it is still possible to obtain valuable information by calibrating MPF stratigraphy to oxygen isotope records from different locations. For example, in the western South Atlantic, we observed that some MPF disappearance and/or 


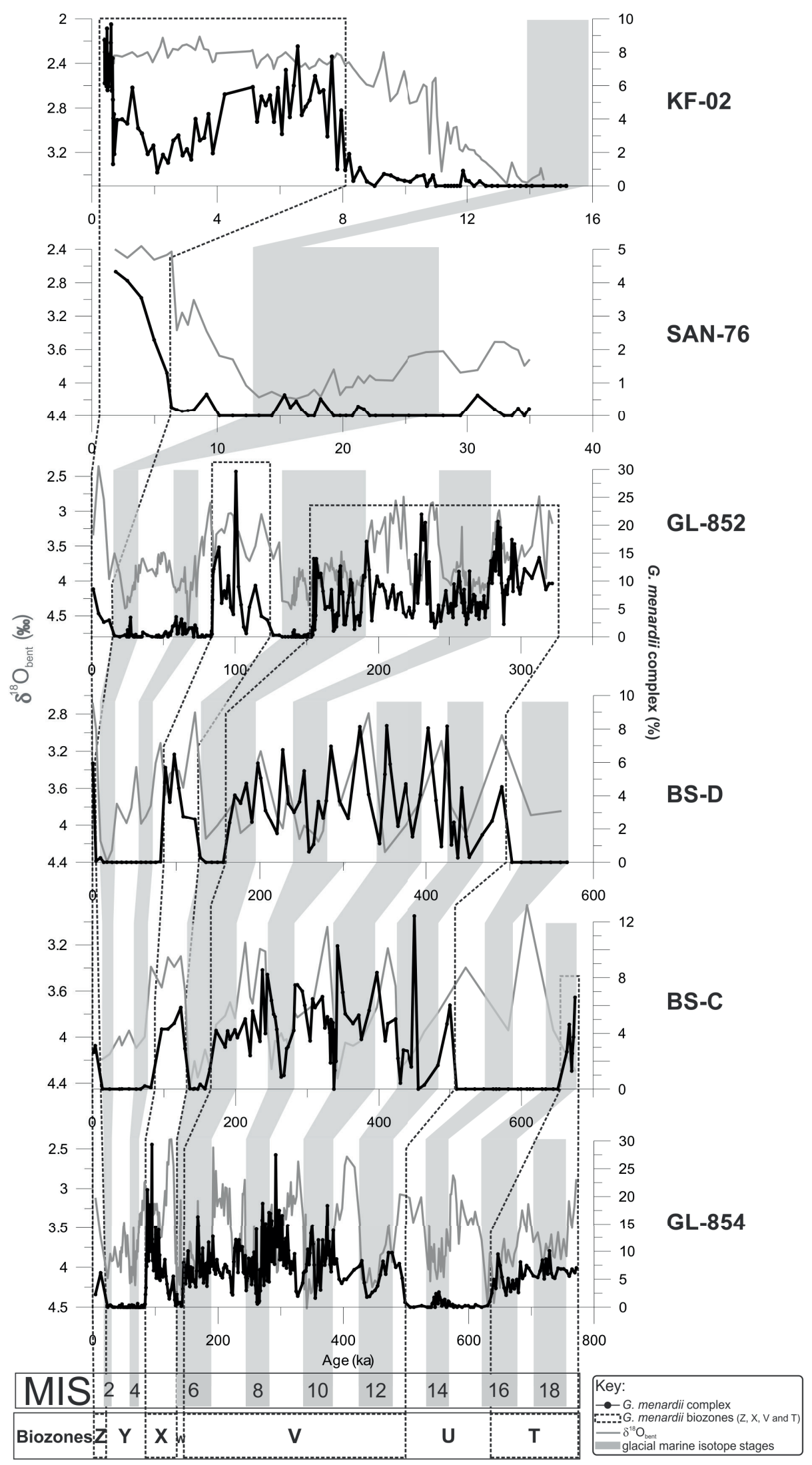

Figure 3. Benthic and planktonic oxygen isotopic record for the cores: KF-02, SAN-76, GL-852, BS-D, BS-C and GL-854 and LR04 stack (reference curve) (Lisiecki \& Raymo, 2005). Grey bands represent glacial marine isotope stages (MIS). Numbers on the curve designates marine isotopic substages. Vertical arrows: AMS ${ }^{14} \mathrm{C}$ datings. Abbreviations: LOEH, Lowest Occurrence of calcareous nannofossil Emiliania huxleyi; HOPL, Highest Occurrence of calcareous nannofossil Pseudoemiliania lacunosa. 


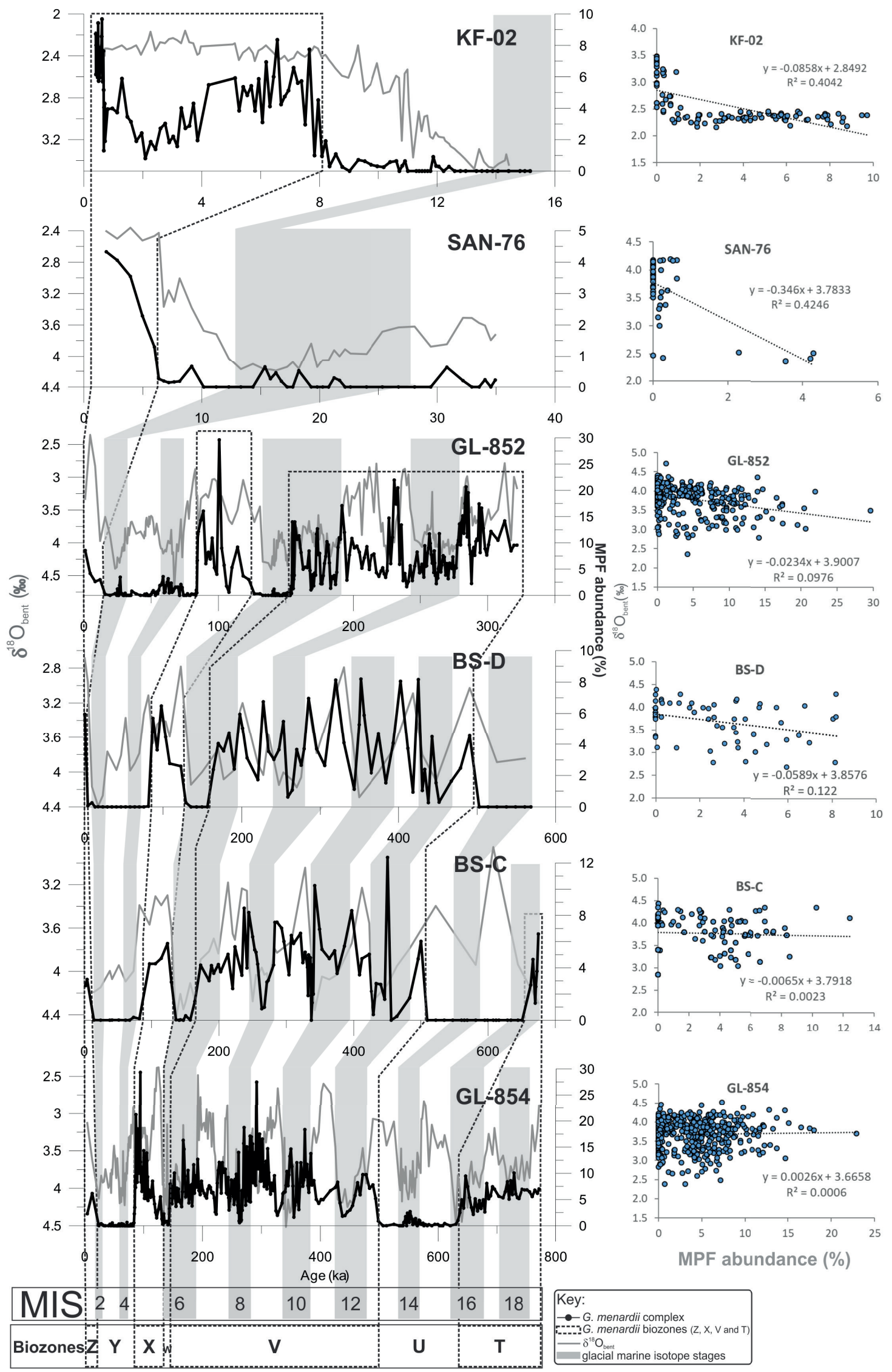

Figure 4. Globorotalia menardii complex relative abundances (\%) (black line) and benthic oxygen isotopic curves $\left(\delta^{18} \mathrm{O}_{\text {ben }}\right)($ grey line) and their linear regression. Dotted lines represent G. menardii biozones. Grey bands represent glacial marine isotope stages (MIS). 
appearance bioevents were diachronous when compared to the Caribbean Sea (Martinez et al., 2007),

The studied cores are well correlated with each other and show a consistent biozone pattern according to the isotopic levels (see Appendix 1; Figure 4). This consistency allowed us to trace and better describe MPF events (i.e. their appearances and disappearances), which characterize the biozone boundaries. The higher the sampling resolution, the higher the accuracy (KF-02; GL-852 and GL-854) (Figure 4). In these cases, it is possible to analyze the distribution of MPF through each biozone.

The oxygen isotope record $\left(\delta^{18} \mathrm{O}\right)$ and the MPF abundance showed here display an inverse relationship, particularly in cores GL-852 and GL-854 (Figure 4). On the other hand, it was reported that the MPF relative abundance and the oxygen isotope record exhibited the same trend in the Caribbean Sea (Martinez et al., 2007). In the Santos Basin, there are persistently low abundances of MPF during interglacial peaks, even in the Biozones $\mathrm{V}$ and $\mathrm{X}$. This pattern is evident in core GL-854 at MIS 17, MIS 15, MIS 13, MIS 11, MIS 9, MIS 7 and MIS 5e; in core BS-C especially at MIS 15, MIS 13, MIS 11 and MIS 9; core BS-D at MIS 5e and in core GL-852 at MIS 7 and MIS 5e (Figure 4). Notably, during the intervals where MPF abundance collapses, such as Biozones $\mathrm{Y}$ and $\mathrm{U}$, there are subtle increases in its abundance within the glacial periods. In the Biozone $\mathrm{Y}$, we verified a slight increase in abundance during the glacial periods MIS 4 (GL-854 and GL852) and MIS 2 (GL-854, GL-852, and SAN-76) (Figure 4). The Biozone U records a similar feature when MPF abundance reaches almost 3\% in glacial MIS 14 (GL-854) (Figure 4).

In order to compare our results in Santos Basin with similar studies, we calculated an average age for biozones (Table 4) and their boundaries (biohorizons) (Table 5) based on all the available cores. Table 4 shows ages for each biozone base and top. Table 5 also presents the best resolution core for each biozone boundary and their respective age. The difference between the mean age and the best core age was relatively small (up to $3 \mathrm{ky}$ ), except for the T/U boundary where the difference was more than $10 \mathrm{ky}$. Our core reliability varies from one to another, not only in terms of number of datings but also because of the sample spacing, which varies from 2 to $52 \mathrm{~cm}$. Although aware of its limitations, we believe that using an average age for all the cores from the same basin is a reasonable approximation, since ages of other localities and environments have been established arbitrarily. According to our data, the Biozone T/U boundary at Santos Basin occurs in MIS $16 \mathrm{~b}$ at $646.1 \mathrm{ka}$. Other studies have shown younger ages for this biohorizon (Martin et al., 1993; Kohl et al., 2004) (Table 6). Even our best resolution core has an age for this boundary of at least $25 \mathrm{ky}$ older than the previously known in Santos Basin. In the same way, U/V boundary took place in MIS 13a (at $499.3 \mathrm{ka}$ ), prior to the age found at the Gulf of Mexico (485 ka) (Kohl et al., 2004), for example. On the other hand, the Santos Basin has the V/W biozone boundary at $156.6 \mathrm{ka}$ (MIS 6c) (Table 5). In this case, it is recorded later than shown in previous studies, such as $186 \mathrm{ka}$ (Kohl et al., 2004) and $200 \mathrm{ka}$ (Martin et al., 1993) for the Gulf of Mexico, or even $186 \mathrm{ka}$ for the Brazilian margin (Vicalvi, 1997, 2013; Ferreira et al., 2012) (Table 6). The age difference between the previous and the present studies for $\mathrm{T} / \mathrm{U}$ and $\mathrm{U} / \mathrm{V}$ boundaries is much larger than the error margin $( \pm 10 \mathrm{ky}$ and $\pm 4 \mathrm{ky}$, respectively) (Table 5). Meanwhile, the boundaries between biozones $\mathrm{W} / \mathrm{X}$ and $\mathrm{X} / \mathrm{Y}$ show small differences from previous results. The first was recorded in the MIS 6/5 boundary at $128.2 \mathrm{ka}$, very close to the age of $127 \mathrm{ka}$ reported by Vicalvi $(1997 ; 2013)$ at the Campos Basin (Brazil), while Kohl et al. (2004) indicated an age of $130 \mathrm{ka}$ at the Gulf of Mexico. The latter was recorded in the Santos Basin at MIS 5b-a (85.4 ka), very close to Vicalvi's (1997; 2013) age (84 ka), and not far from Kohl et al. (2004) and Martin et al. (1993) at the Gulf of Mexico, 89 and $90 \mathrm{ka}$ (MIS 5b) respectively. The age difference between these studies and ours is within the error margin ( \pm 2 ky and $\pm 3 \mathrm{ky}$ ) (Table 5).

Table 4. Average age of base and top samples of Globorotalia menardii biozones for Santos Basin.

\begin{tabular}{cccc}
\hline Biozones & Base age (ka) & Top age (ka) & MIS** interval \\
\hline Z & $7.3 \pm 4(6)^{*}$ & Recent & 1 \\
Y & $82.9 \pm 1(4)$ & $11.8 \pm 12(6)$ & $5 \mathrm{~b}-1$ \\
X & $127.3 \pm 5(4)$ & $88.4 \pm 8(4)$ & $5-5 \mathrm{~b}$ \\
W & $151.3 \pm 13(4)$ & $132 \pm 4(4)$ & $6-6 / 5$ \\
V & $495 \pm 4(3)$ & $156 \pm 17(4)$ & $13-6$ \\
U & $642.1 \pm 8.5(2)$ & $503.6 \pm 6(3)$ & $16-13$ \\
T & - & $650.1 \pm 13(2) *$ & $19-16$ \\
\hline
\end{tabular}

* Numbers in parenthesis designate the numbers of cores utilized.

**MIS - Marine Isotope Stage

We observed the $\mathrm{Y} / \mathrm{Z}$ boundary at $9.7 \mathrm{ka}$ (MIS 1), although previous studies pointed to a different age, $11 \mathrm{ka}$ (Vicalvi, 1997, 2013; Kohl et al., 2004; Portilho-Ramos et al., 2006; Ferreira et al., 2012), which is within the margin of error $( \pm 5$ $\mathrm{ky})$. However, we believe that the average difference of $2 \mathrm{ky}$ between the Santos Basin and the tropical Atlantic could be even greater because the two higher resolution cores for this interval (KF-02 and SAN-76) show even younger ages. If we consider that four of the six studied cores (GL-854, GL-852, BS-C, and BS-D) did not have the ideal resolution for this bioevent, and calculate the $\mathrm{Y} / \mathrm{Z}$ boundary age by an average between KF-02 and SAN-76, we obtain an age of only $7 \pm 2 \mathrm{ka}$. The sample spacing of these two cores is close enough to capture the finest details of the record of the most recent MPF reappearance event.

The biozone boundary ages presented here for the continental slope of the Santos Basin (Table 5) give rise to an important debate upon the use of the MPF as a guide for biostratigraphers, both in the industry and in academia. When comparing these results to those of previous studies involving MPF stratigraphy and their biozone ages, we found age differences varying from 1.3-1.8 ky on the $\mathrm{Y} / \mathrm{Z}, \mathrm{X} / \mathrm{Y}$ and $\mathrm{W} / \mathrm{X}$ boundary to 36.1-121.1 ky on the T/U boundary (Table 6). In U/V boundary age differences were around $14 \mathrm{ky}$, while in $\mathrm{V} / \mathrm{W}$ boundary it achieved 30 to $43.4 \mathrm{ky}$. 
Table 5. Average age of Globorotalia menardii biozones boundaries and the correspondent marine isotope stage (MIS).

\begin{tabular}{|c|c|c|c|c|c|c|c|c|}
\hline Boundaries & $\begin{array}{l}\text { Age (ka) } \\
\text { (average) }\end{array}$ & $\begin{array}{c}\text { sampling } \\
\text { resolution }(\mathrm{cm})\end{array}$ & $\max -\min (\mathrm{cm})$ & MIS & $\begin{array}{l}\text { Age (ka) } \\
\text { (best core) }\end{array}$ & $\begin{array}{c}\text { sampling } \\
\text { resolution }(\mathrm{cm})\end{array}$ & core & MIS \\
\hline $\mathrm{Z} / \mathrm{Y}$ & $9.7 \pm 5.22$ & $11.5(6)^{*}$ & $2-30$ & 1 & $8.0 \pm 0.03$ & 2 & KF-02 & 1 \\
\hline $\mathrm{Y} / \mathrm{X}$ & $85.4 \pm 2.34$ & $24(4)$ & $5-52$ & $5 b$ & $84.0 \pm 0.33$ & 5 & GL-854 & $5 \mathrm{~b}$ \\
\hline $\mathrm{X} / \mathrm{W}$ & $128.2 \pm 3.33$ & $14(4)$ & $5-20$ & $5 e$ & $129.8 \pm 1.14$ & 5 & GL-854 & $5 \mathrm{e}$ \\
\hline $\mathrm{W} / \mathrm{V}$ & $156.6 \pm 9.13$ & $17(4)$ & $5-33$ & $6 c$ & $154.3 \pm 0.16$ & 5 & GL-852 & $6 \mathrm{c}$ \\
\hline $\mathrm{V} / \mathrm{U}$ & $499.3 \pm 4.11$ & $19(3)$ & $3-31$ & $13 a$ & $496.2 \pm 2.30$ & 3 & GL-854 & $13 \mathrm{a}$ \\
\hline $\mathrm{U} / \mathrm{T}$ & $646.1 \pm 10.92$ & $18(2)$ & $5-30$ & $16 \mathrm{~b}$ & $635.2 \pm 1.63$ & 5 & GL-854 & $16 \mathrm{a}$ \\
\hline
\end{tabular}

* Numbers in parenthesis designates the numbers of cores utilized.

Table 6. Comparison of ages from previous studies based on G. menardii stratigraphy and this study.

\begin{tabular}{|c|c|c|c|c|c|c|c|c|}
\hline \multirow[t]{2}{*}{ Biozones } & \multicolumn{2}{|c|}{ Caribbean Sea } & \multicolumn{2}{|c|}{ Gulf of Mexico } & \multirow{2}{*}{$\begin{array}{c}\text { Campos Basin } \\
\text { (Brazil) }\end{array}$} & \multicolumn{3}{|c|}{$\begin{array}{l}\text { Santos Basin } \\
\text { (Brazil) }\end{array}$} \\
\hline & $\begin{array}{l}\text { Martin et al. } \\
\quad(1990)\end{array}$ & $\begin{array}{l}\text { Martinez et al. } \\
\quad \text { (2007) }\end{array}$ & $\begin{array}{l}\text { Martin et al. } \\
\quad(1993)\end{array}$ & $\begin{array}{l}\text { Kohl et al. } \\
\text { (2004) }\end{array}$ & & $\begin{array}{l}\text { Portilho et al. } \\
\text { (2006) }\end{array}$ & $\begin{array}{l}\text { Ferreira et al. } \\
\quad(2012)\end{array}$ & this study \\
\hline & & & (ka) & (ka) & (ka) & (ka) & (ka) & (ka)/ MIS \\
\hline $\mathrm{Z} / \mathrm{Y}$ & MIS 1 & MIS 1 & - & 11 & 11 & 11.5 & 11 & $9.7 \pm 5 / 1$ \\
\hline $\mathrm{Y} / \mathrm{X}$ & MIS 5 & MIS 5 & 90 & 89 & 84 & 84 & 84 & $85.4 \pm 2 / 5 b$ \\
\hline $\mathrm{X} / \mathrm{W}$ & MIS 6/5 & MIS 6/5 & - & 130 & $127 / 130$ & - & 130 & $128.2 \pm 3 / 5 \mathrm{e}$ \\
\hline $\mathrm{W} / \mathrm{V}$ & MIS 7/6 & MIS 6 & 200 & 186 & 186 & - & 186 & $156.6 \pm 9 / 6 \mathrm{c}$ \\
\hline $\mathrm{V} / \mathrm{U}$ & MIS 13 & MIS 13 & - & 485 & 485 & - & 485 & $499.3 \pm 4 / 13 a$ \\
\hline $\mathrm{U} / \mathrm{T}$ & MIS 16 & - & $620-525$ & 610 & 610 & - & 610 & $646.1 \pm 10 / 16 b$ \\
\hline
\end{tabular}

The mechanisms of the cyclic and dramatic plankton population oscillations that generate the Atlantic's MPF stratigraphy are still unclear (Sexton \& Norris, 2011; Broecker \& Pena, 2014). The diachronism associated with MPF evidenced by the present data is probably a key point to understanding the driving mechanism of their cyclic presence/ absence phenomenon in the Atlantic Ocean. Some discussions have risen upon the repopulation of MPF in the Atlantic Ocean that took place several thousand years after the onset of the Holocene (core 1 in Sexton \& Norris, 2011; Pivel et al., 2013; Broecker \& Pena, 2014, this work); our results agree with such studies. The common age for Biozones Y/Z were 11ka (Ericson \& Wollin, 1968, Vicalvi, 1997; 2013; Kohl et al., 2004; Portilho-Ramos et al., 2006; Sexton \& Norris, 2011, Ferreira et al., 2012), which coincide with the onset of the Holocene (ISC, 2018). On the other hand, the limit between the glacial MIS 2 and the interglacial MIS 1 is at 14 ka (Lisiecki \& Raymo, 2005, Railsback et al., 2015). Finally, the last MPF reappearance event were recorded between 7 and $8 \mathrm{ka}$ in the Santos Basin (Pivel et al., 2013, this work), that is 6-7 ky after the onset of the modern interglacial and 3-4 ky after the onset of the Holocene. As shown in Figure 4 (GL-854 and GL-852) this 'out of phase' repopulation is a persistent feature during the last $772 \mathrm{ky}$ and should be better investigated in studies of the mechanisms behind the cyclic MPF occurrence throughout the Atlantic Ocean.

The different ages observed along the Atlantic Ocean for the MPF disappearances and reappearances demands caution when comparing results to data from other studies or adopting other studies data as a chronological guide. Although studies have already pointed out discrepancies in the use of the menardiiform planktonic species as paleoclimatic indicators (Martin et al., 1993; Martinez et al., 2007), it is still common to use their abundance as an indicator of glacial and interglacial periods (Vicalvi, 1999; Portilho-Ramos et al., 2006; Ferreira et al., 2012; Portilho-Ramos et al., 2014). Our results have shown that the idea of a climatic zonation based on MPF stratigraphy is not recommended. In addition, we suggest that some ages usually assigned to MPF stratigraphy events in Brazilian marginal basins must be reviewed based on local age models. The diachronism of MPF events must be especially considered when used for accumulation rates estimates, both for paleoclimate studies or assessment of sediment stability on the continental slope.

Comparison of MPF stratigraphy and the oxygen isotopic record has shown that there is no relationship between them in the western South Atlantic (Figure 4). The development of local age models is important to better understand how the environment responds to global and regional changes, and more specifically, to identify when an event is diachronous or not.

\section{CONCLUSIONS}

This study presents a chronostratigraphic framework for the western South Atlantic MPF stratigraphy during the past $772 \mathrm{ky}$. Biostratigraphic zones are temporally calibrated using benthic foraminifera oxygen isotope stratigraphy. It is possible to identify diachronous bioevents when compared to existing data 
from the Caribbean Sea and the Gulf of Mexico. The framework is useful for paleoceanographic studies and for the geohazard assessment of the continental slope when MPF stratigraphy is used to attribute ages for sediments. We also support that the persisting absence of MPF cannot be used freely as synonymous to glacial periods, as well as its abundant presence does not mean interglacial periods as suggested by the "bioclimatic zonation" frequently employed in MPF stratigraphy. Although not within the scope of this work, we believe that the new results presented here show that the diachronism in MPF seems to be an important feature in understanding the causes of its cyclicity in the Atlantic Ocean. For that reason, we reinforce here that an isotopic chronostratigraphic control is essential for inter-basin comparisons.

\section{ACKNOWLEDGMENTS}

This study is a contribution of Applied Micropaleontology Program, funded by the National Petroleum Agency (ANP) and São Paulo Research Foundation (FAPESP) grant 2013/50224-2. We thank Petrobras for providing the samples. The authors are grateful to scientists and staff of the South Atlantic Paleoceanographic Lab - (LaPAS-IOUSP) for sample preparation and technical support. We are especially grateful to R. Kowsmann who recognized the necessity of integrating accurate biostratigraphic and isotopic data for Santos Basin and for useful discussions. The authors wish to express their thanks to J.-A. Flores and R. Kowsmann who proofread an early version of this manuscript.

\section{REFERENCES}

Araújo, T.M.F. \& Machado, A.J. 2008. Eventos bioestratigráficos, paleoclimáticos e paleobatimétricos do talude continental superior da Bahia, evidenciado através do estudo da fauna de foraminíferos. Gravel, 6:27-45.

Bé, A.W.H.; Damuth, J.E.; Lott, L. \& Free, R. 1976. Late Quaternary climatic record in western equatorial Atlantic sediment. In: R.M. Cline \& J.D. Hays (eds.) Investigation of Late Quaternary Paleoceanography and Paleoclimatology, Boulder, The Geological Society of America, p. 165-200 (Memoirs 145). doi:10.1130/MEM145-p165

Boebel, O.; Schmid, C.; Podesta, G. \& Zenk, W. 1999. Intermediate water in the Brazil-Malvinas confluence zone: a Lagrangian view. Journal of Geophysical Research, 104:21063-21082. doi:10.1029/1999JC900059

Briskin, M. \& Berggren, W.A. 1975. Pleistocene stratigraphy and quantitative paleo-oceanography of tropical North Atlantic core V16-205. In: T. Saito \& L.H. Burckle (eds.) Late Neogene epoch boundaries, American Museum of Natural History, p. 167-198.

Broecker, W. \& Pena, L.D. 2014. Delayed Holocene reappearance of G. menardii. Paleoceanography and Paleoclimatology, 29:291-295. doi:10.1002/2013PA002590

Butzin, M.; Prange, M. \& Lohmann, G. 2005. Radiocarbon simulations for the glacial ocean: the effects of wind stress, Southern Ocean sea ice and Heinrich events. Earth and Planetary Science Letters, 235:45-61. doi:10.1016/j.epsl.2005.03.003

Camillo Jr., E.; Quadros, J.P.; Costa, K.B. \& Toledo, F.A.L. 2015. Análises faunística e multivariada de foraminíferos planctônicos da Bacia Pernambuco-Paraíba: uma interpretação paleoambiental dos últimos 30 mil anos. Revista Brasileira de Paleontologia, 18:109-120. doi:10.4072/rbp.2015.1.08

Campos, E.J.D.; Gonçalves, J.E. \& Ikeda, Y. 1995. Water mass characteristics geostrophic circulation in the South Brazil bight: summer of 1991. Journal of Geophysical Research, 100:18537-18550. doi:10.1029/95JC01724

Campos, E.J.D.; Velhote, D. \& Silveira, I.C.A. 2000. Shelf break upwelling driven by Brazil Current cyclonic meanders. Geophysical Research Letters, 27:751-754. doi:10.1029/1999GL010502

Chiessi, C.M.; Ulrich, S.; Mulitza, S.; Pätzold, J. \& Wefer, G. 2007. Signature of the Brazil-Malvinas Confluence (Argentine Basin) in the isotopic composition of planktonic foraminifera from surface sediments. Marine Micropaleontology, 64:52-66. doi:10.1016/j.marmicro.2007.02.002

Cremer, M.; Gonthier, E.; Duprat, J.; Faugères, J. \& Courp, T. 2007. Late Quaternary variability of the sedimentary record in the São Tome deep-sea system (South Brazilian basin). Marine Geology, 236:223-245. doi:10.1016/j.margeo.2006.10.032

Curry, W.B. \& Lohmann, G.P. 1982. Carbon isotopic changes in benthic Foraminifera from the Western South-Atlantic - Reconstruction of glacial abyssal circulation patterns. Quaternary Research, 18:218-235. doi:10.1016/00335894(82)90071-0

Damuth, J.E. 1975. Quaternary climate change as revealed by calcium-carbonate fluctuations in western equatorial Atlantic sediments. Deep Sea Research and Oceanographic Abstracts, 22:725-743. doi:10.1016/0011-7471(75)90078-9

Duarte, C.S.L. \& Viana, A.R. 2007. Santos drift system: stratigraphic organization and implications for the late Cenozoic palaeocirculation in the Santos Basin, SW Atlantic Ocean. In: A.R. Viana \& M. Rebesco (eds.) Economic and palaeoceanographic significance of contourite deposits, London, Geological Society, p. 171-198 (Special Publications 276). doi:10.1144/GSL.SP.2007.276.01.09

Ericson, D.B. \& Wollin, G. 1968. Pleistocene climates and chronology in deep-sea sediments. Science, 162:1227-1234. doi:10.1126/science.162.3859.1227

Fairbanks, R.G.; Mortlock, R.A.; Chiu, T.-C.; Cao, L.; Kaplan, A.; Guilderson, T.P.; Fairbanks, T.W. \& Bloom, A.L. 2005. Marine radiocarbon calibration curve spanning 10,000 to 50,000 years B.P. based on paired ${ }^{230} \mathrm{Th} /{ }^{234} \mathrm{U} / 238 \mathrm{U}$ and ${ }^{14} \mathrm{C}$ dates on pristine corals. Quaternary Science Reviews, 24:1781-1796. doi:10.1016/j.quascirev.2005.04.007

Ferreira, F.; Leipnitz, I.I.; Vicalvi, M.A. \& Sanjinés, A.E.S. 2012. Zoneamento Paleoclimático do Quaternário da Bacia de Santos com base em foraminíferos planctônicos. Revista Brasileira de Paleontologia, 15:173-188. doi:10.4072/rbp.2012.2.06

Goni, G.J. \& Wainer, I. 2001. Investigation of the Brazil Current front variability from altimeter data. Journal of Geophysical Research, 106:31117-31128. doi:10.1029/2000JC000396

Hayward, B.W.; Le Coze, F. \& Gross, O. 2018. World Foraminifera Database. Available at http://marinespecies.org/aphia. $\mathrm{php}$ ? $\mathrm{p}=$ taxdetails\&id=418115; accessed on 09/01/2018.

Johns, W.E.; Lee, T.N.; Beardsley, R.C.; Candela, J.; Limeburner, R. \& Castro, B. 1998. Annual cycle and variability of the North Brazil current. Journal of Physical Oceanography, 28:103-128. doi: 10.1175/1520-0485(1998)028<0103:ACAVOT>2.0.CO;2

Kim, J.H. \& Schneider, R.R. 2003. Low-latitude control of interhemispheric sea-surface temperature contrast in the tropical Atlantic over the past 21 kyears: the possible role of SE trade winds. Climate Dynamics, 21:337-347. doi:10.1007/s00382003-0341-5

Kohl, B.; Fillon, R.H. \& Roberts, H.H. 2004. Foraminiferal biostratigraphy and paleoenvironments of the Pleistocene 
Lagniappe delta and related section, northeastern Gulf of Mexico. In: J.B. Andersen \& R. Fillon (eds.) Late Quaternary stratigraphic evolution of the Gulf of Mexico basin, Tulsa, Society for Sedimentary Geology, p. 189-216 (Special Publication 79). doi:10.2110/pec.04.79.0189

Kowsman, R.O.; Lima, A.C. \& Vicalvi, M.A. 2015. Feições indicadoras de instabilidade geológica no talude continental e no Platô de São Paulo. In: R.O. Kowsmann (ed.) Geologia e Geomorfologia, Elsevier, p. 71-98. doi:10.1016/B978-85-3526937-6.50012-4

Lisiecki, L.E. \& Raymo, M.E. 2005. A Pliocene-Pleistocene stack of 57 globally distributed benthic $\delta^{18} \mathrm{O}$ records. Paleoceanography, 20:PA2007. doi:10.1029/2004PA001071

Martin, R.E. \& Fletcher, R.R. 1995. Graphic correlation of PlioPleistocene sequence boundaries, Gulf of Mexico: oxygen isotopes, ice volume, and sea level. In: K.O. Mann \& H.R. Lane (eds.) Graphic correlation and the composite standard: the methods and their applications, Tulsa, Society for Sedimentary Geology, p. 235-248 (Special Publication 53). doi:10.2110/ pec.95.53.0235

Martin, R.E.; Neff, E.D.; Johnson, G.W. \& Krantz, D.E. 1990. Biostratigraphy of the Pleistocene: the Ericson and Wollin zonation revisited. In: SEQUENCE STRATIGRAPHY AS AN EXPLORATION TOOL: CONCEPTS AND PRACTICES IN THE GULF COAST, 11, 1990. Program with papers, Society of Economic Paleontologists and Mineralogists, Houston, p. 229-236.

Martin, R.E.; Neff, E.D.; Johnson, G.W. \& Krantz, D.E. 1993. Pleistocene sequence boundaries Gulf of Mexico. Palaios, 8:155-171. doi:10.2307/3515169

Martinez, J.I.; Mora, G. \& Barrows, T.T. 2007. Paleoceanographic conditions in the western Caribbean Sea for the last $560 \mathrm{kyr}$ as inferred from planktonic foraminifera. Marine Micropaleontology, 64:177-188. doi:10.1016/j.marmicro.2007.04.004

Matano, R.P.; Schlax, M.G. \& Chelton, D.B. 1993. Seasonal variability in the southwestern Atlantic. Journal of Geophysical Research, 98:18027-18035. doi:10.1029/93JC01602

Mohriak, W.U.; Szatmari, P. \& Anjos, S. 2012. Salt: geology and tectonics of selected Brazilian basins in the global context. In: G.I. Alsop; S.G. Archer; A.J. Hartley; N.T. Grant \& R. Hodgkinson (eds.) Salt tectonics, sediments and prospectivity, London, Geological Society, p. 131-158 (Special Publication 363).

Oliveira, D.H.; Mello, R.M.; Barreto, A.M.F. \& Strohschoen Jr., O. 2007. O limite Pleistoceno/Holoceno no Campo de Marlim Leste da Bacia de Campos - RJ, com base na bioestratigrafia de foraminíferos planctônicos. Estudos Geológicos, 17:41-50.

Paillard, D.; Labeyrie, L. \& Yiou, P. 1996. Macintosh programperforms time-series analysis. Eos, Transactions, American Geophysical Union, 77:379-379. doi:10.1029/96EO00259

Pätzold, J.; Bickert, T.; Bruck, L.; Gaedicke, C.; Heidland, K.; Meinecke, G. \& Mulitza, S. 1993. Berichtunderste Ergebnisseüber die METEOR-Fahrt M 15/2, Rio de Janeiro Vitória, 18.1-7.21. Berichte, FachbereichGeowissenschaften, Universität Bremen, $49 \mathrm{p}$.

Pätzold, J. et al. 1999. Report and preliminary results of METEORCruise M 41/3, Vitória - Salvador, 18.4-15.5. Berichte, Fachbereich Geowissenschaften, Universität Bremen, 160 p.

Pisias, N.G.; Martinson, D.G.; Moore, T.C.; Shackleton, N.J.; Prell, W.; Hays, J. \& Boden, G. 1984. High resolution stratigraphic correlation of benthic oxygen isotopic records spanning the last 300,000 years. Marine Geology, 56:119-136 doi:10.1016/0025-3227(84)90009-4

Pivel, M.A.G.; Santarosa, A.C.A.; Toledo, F.A.L. \& Costa, K.B. 2013. The Holocene onset in the southwestern South Atlantic. Palaeogeography, Palaeoclimatology, Palaeoecology, 374:164172. doi:10.1016/j.palaeo.2013.01.014

Portilho-Ramos, R.C.; Barbosa, C.F. \& Rios-Netto, A.M. 2014. Planktonic foraminiferal variations in the southwestern Atlantic since the last glacial-interglacial cycle. Palaios, 29:38-44. doi:10.2110/palo.2012.104

Portilho-Ramos, R.C.; Rios-Netto, A.M. \& Barbosa, C.F. 2006. Caracterização bioestratigráfica do Neógeno Superior da Bacia de Santos com base em foraminíferos planctônicos. Revista Brasileira de Paleontologia, 9:349-354.

Railsback, L.B.; Gibbard, P.L.; Head, M.J.; Voarintsoa, N.R.G. \& Toucanne, S. 2015. An optimized scheme of lettered marine isotope substages for the last 1.0 million years, and the climatostratigraphic nature of isotope stages and substages. Quaternary Science Reviews, 111:94-106. doi:10.1016/j. quascirev.2015.01.012

Rodrigues, M.A.C. \& Carvalho, M.G.P. 1980. Curvas paleoclimáticas com base em foraminíferos de testemunhos da plataforma sulbrasileira. Anais da Academia Brasileira de Ciências, 52:617-625.

Rodrigues, R.; Rothstein, L.M. \& Wimbush, M. 2007. Seasonal variability of the south equatorial current bifurcation in the Atlantic Ocean: a numerical study. Journal of Physical Oceanography, 37:16-30. doi:10.1175/JPO2983.1

Ruddiman, W.F. \& McIntyre, A. 1979. Warmth of the subpolar North Atlantic during Northern Hemisphere ice-sheet growth. Science, 204:173-175. doi:10.1126/science.204.4389.173

Ruddiman, W.F. \& McIntyre, A. 1981. Oceanic mechanisms for amplification of the 23,000-year ice-volume cycle. Science, 212:617-627. doi:10.1126/science.212.4495.617

Ruddiman, W.F.; Raymo, M.E. \& McIntyre, A. 1986. Matuyama 41,000-year cycles: North Atlantic ocean and northern hemisphere ice sheets. Earth and Planetary Science Letters, 80:117-129. doi:10.1016/0012-821X(86)90024-5

Sanjinés, A.E.S. 2006. Biocronoestratigrafia de foraminíferos em três testemunhos do Pleistoceno-Holoceno do talude continental da Bacia de Campos, RJ - Brasil. Instituto de Geociências, Universidade Federal do Rio de Janeiro, Dissertação de mestrado, $119 \mathrm{p}$.

Schott, W. 1935. Die foraminiferen in dem equatorialen teil des Atlantischen Ozeans. Wissenchaftliche Eregebnisse der Deutsche, Atlantischen Expedition "Meteor". 1925-1927, 134 p.

Sexton, P.F. \& Norris, R.D. 2011. High latitude regulation of low latitude thermocline ventilation and planktic foraminifer populations across glacial-interglacial cycles. Earth Planetary Science Letters, 311:69-81. doi:10.1016/j.epsl.2011.08.044

Shackleton, N.J. \& Hall, M.A. 1984. Oxygen and carbon isotope stratigraphy of Deep Sea Drilling project hole 552A: PlioPleistocene glacial history. In: D. Roberts et al. (eds.) Initial Reports DSDP, p. 599-609. doi:10.2973/dsdp.proc.81.116.1984

Stramma, L. \& England, M. 1999. On the water masses and mean circulation of the South Atlantic Ocean. Journal of Geophysical Research, 104:20863-20883. doi:10.1029/1999JC900139

Streeter, S.S. \& Shackleton, N.J. 1979. Paleocirculation of the deep North Atlantic: 150,000-year record of benthic foraminifera and oxygen-18. Science, 203:168-171. doi:10.1126/ science.203.4376.168

Thunnel, R.C. 1984. Pleistocene planktonic foraminiferal biostratigraphy and paleoclimatology of the Gulf of Mexico. In: N. Healy-Williams (ed.) Principles of Pleistocene stratigraphy applied to the Gulf of Mexico, International Human Resources Development Corporation, p. 25-64.

Toledo, F.A.L. 2000. Variações paleoceanográficas nos últimos 30.000 anos no oeste do Atlântico Sul: isótopos de oxigênio, assembleia de foraminíferos planctônicos e nanofósseis calcários. Universidade Federal do Rio Grande do Sul, Instituto de Geociências, Tese de doutorado, 245 p.

Toledo, F.A.L.; Cachão, M.; Costa, K.B. \& Pivel, M.A.G. 2007. Planktonic foraminifera, calcareous nannoplankton and ascidian variations during the last $25 \mathrm{kyr}$ in the Southwestern Atlantic: 
a paleoproductivity signature? Marine Micropaleontology, 64:67-79. doi:10.1016/j.marmicro.2007.03.001

Toledo, F.A.L.; Quadros, J.P.; Camillo Jr., E.; Santarosa, A.C.A.; Flores, J.-A. \& Costa, K.B. 2016. Plankton biochronology for the last 772,000 years from western South Atlantic Ocean. Marine Micropaleontology, 127:50-62. doi:10.1016/j. marmicro.2016.07.002

Vicalvi, M.A. 1997. Zoneamento bioestratigráfico e paleoclimático dos sedimentos do Quaternário Superior do Talude da Bacia de Campos. Boletim de Geociencias da PETROBRAS, 11:132-165.

Vicalvi, M.A. 1999. Zoneamento bioestratigráfico e paleoclimático do Quaternário Superior do talude da Bacia de Campos e Platô de São Paulo adjacente, com base em foraminíferos planctônicos. Universidade Federal do Rio de Janeiro, Tese de Doutorado, 183 p.
Vicalvi, M.A. 2013. Distribuição estratigráfica quantitativa de foraminíferos planctônicos no Quaternário da margem continental do Sudeste brasileiro. Boletim de Geociências da PETROBRAS, 21:357-368.

Vicalvi, M.A. \& Palma, J.J.C. 1980. Bioestratigrafia e taxas de acumulação dos sedimentos quaternários do talude do sopé continental entre a Foz do Rio Gurupi (MA) e Fortaleza (CE). Boletim Técnico da PETROBRAS, 23:3-11.

Wienders, N.; Arhan, M. \& Mercier, H. 2000. Circulation at the western boundary of the South and Equatorial Atlantic: exchanges with the ocean interior. Journal of Marine Research, 58:1007-1039. doi:10.1357/002224000763485782

Received in 22 January, 2018; Accepted in 15 September, 2018.

Appendix 1. Summary of MPF biozones in studied cores.

\begin{tabular}{|c|c|c|c|c|c|c|}
\hline Core ID & Biozone G. menardii & Number of samples & $\begin{array}{c}\text { Mean MPF } \\
\text { abundance (\%) }\end{array}$ & MIS* & Age (ka) (base-top) & Time span (ka) \\
\hline \multirow[t]{2}{*}{ KF-02 } & $\mathrm{Z}$ & 70 & 4.90 & 1 & $8-0.390$ & 7.6 \\
\hline & $\mathrm{Y}$ & 40 & 0.27 & $2-1$ & $14.4-8.1$ & 6.3 \\
\hline \multirow[t]{2}{*}{ SAN-76 } & $\mathrm{Z}$ & 5 & 3.10 & 1 & $6-1.9$ & 4.1 \\
\hline & $\mathrm{Y}$ & 38 & 0.14 & $3-1$ & $35-6.4$ & 28.6 \\
\hline \multirow[t]{5}{*}{ GL-852 } & $\mathrm{Z}$ & 4 & 4.50 & 1 & $12.2-1.1$ & 11.1 \\
\hline & $\mathrm{Y}$ & 79 & 0.64 & $5 b-2 / 1$ transition & $83.9-15.8$ & 68.1 \\
\hline & $\mathrm{X}$ & 20 & 8.50 & $5 e-5 b$ & $122.4-84.3$ & 38.1 \\
\hline & $\mathrm{W}$ & 45 & 0.20 & $6 c-6 a$ & $142-128.5$ & 13.5 \\
\hline & $\mathrm{V}$ & 154 & 7.6 & $9-6 c$ & $322-154.5$ & 167.5 \\
\hline \multirow[t]{6}{*}{ BS-D } & Z & 1 & 5.90 & 1 & 0.350 & - \\
\hline & $\mathrm{Y}$ & 15 & 0.03 & $5 b-2 / 1$ transition & $81.3-4.3$ & 77 \\
\hline & $\mathrm{X}$ & 6 & 4.30 & $5 e-5 b$ & $122.5-87.1$ & 35.4 \\
\hline & W & 5 & 0.05 & $6 c-6 a$ & $156-129$ & 27 \\
\hline & $\mathrm{V}$ & 45 & 3.7 & $13-6$ & $490.5-163.8$ & 326.7 \\
\hline & $\mathrm{U}$ & 7 & 0 & $14-13$ & $568.4-502.6$ & 65.8 \\
\hline \multirow[t]{7}{*}{ BS-C } & $\mathrm{Z}$ & 2 & 2.80 & 1 & $4.4-2.1$ & 2.3 \\
\hline & $\mathrm{Y}$ & 9 & 0.04 & $5 b-2 / 1$ transition & $82-14.4$ & 67.6 \\
\hline & $\mathrm{X}$ & 5 & 4.40 & $5 e-5 b$ & $129.4-87$ & 42.4 \\
\hline & $\mathrm{W}$ & 7 & 0.30 & $6 c-6 a$ & $164-136$ & 28 \\
\hline & $\mathrm{V}$ & 62 & 4.4 & $13-6$ & $500.4-172.7$ & 327.7 \\
\hline & $\mathrm{U}$ & 17 & 0 & $16 a-13$ & $650.7-510$ & 140.7 \\
\hline & $\mathrm{T}$ & 6 & 3.6 & $16 \mathrm{a}$ & $674-663$ & 11 \\
\hline \multirow[t]{7}{*}{ GL-854 } & $\mathrm{Z}$ & 2 & 4.20 & 1 & 12.84 .4 & 8.4 \\
\hline & $\mathrm{Y}$ & 68 & 0.08 & $5 b-2 / 1$ transition & 83.623 .9 & 59.7 \\
\hline & $\mathrm{X}$ & 45 & 9.20 & $5 e-5 b$ & 128.784 .3 & 44.4 \\
\hline & W & 10 & 0.80 & $6 c-6 a$ & 142.7130 .9 & 11.8 \\
\hline & $\mathrm{V}$ & 197 & 8 & $13-6 c$ & $494-144$ & 350 \\
\hline & $\mathrm{U}$ & 46 & 0.5 & $16 a-13$ & $633.6-498.5$ & 135.1 \\
\hline & $\mathrm{T}$ & 38 & 5.8 & $19-16 a$ & $772-637$ & 135 \\
\hline
\end{tabular}

*MIS - Marine Isotope Stage

Appendix 2. Menardiiform Planktonic Foraminifera mentioned in the text:

Globorotalia menardii (d'Orbigny, 1865), [ = Globorotalia cultrata (d'Orbigny)]

Globorotalia tumida (Brady, 1877)

Globorotalia flexuosa (Koch, 1923)

Globorotalia ungulata (Brady, 1884) 